\title{
Chemical and biological indicators of water quality in three agricultural watersheds of the Po valley, Italy
}

\author{
Linda Pieri, ${ }^{1}$ Francesca Ventura, ${ }^{1}$ Maurizio Ventura, ${ }^{2}$ Massimo Tagliavini, ${ }^{3}$ Massimo Ponti, ${ }^{4}$ \\ Rossella Pistocchi, ${ }^{4}$ Sergio Albertazzi, ${ }^{1}$ Marco Vignudelli, ${ }^{1}$ Paola Rossi Pisa' \\ ${ }^{1}$ Department of Agroenvironmental Science and Technology, University of Bologna; ${ }^{2}$ Department \\ of Fruit and Woody Plant Sciences, University of Bologna; ${ }^{3}$ Faculty of Science and Technology, \\ Free University of Bolzano; ${ }^{4}$ C.I.R.S.A., University of Bologna, Italy
}

\begin{abstract}
Agriculture has both direct and indirect effects on quality of surface water and is one of the key activities causing water quality degradation. Its environmental impact can be evaluated by the determination of indicators of the quality of water bodies that collect drainage and runoff waters from agricultural watersheds. For this research, the water quality draining from three watersheds, totally or partially cultivated, all within the Po river valley (Italy), was determined, using chemical indicators ( $\mathrm{N}-\mathrm{NO}_{3}$ and $\mathrm{N}-\mathrm{NH} 4$ concentration, $\mathrm{N}$ balance), trophic status (chlorophyll-a concentration) and benthic population indexes. Together, they should provide an overview of the water status, which is supposed to be strictly related to the land use and the management. Results show that the chemical parameters are well related to land use and farming management: intensive agricultural activity leads to high $\mathrm{N}-\mathrm{NO}_{3}$ concentration in water and $\mathrm{N}$ surplus and vice versa. The chlorophyll-a concentration follows the same trend, being linked to nitrogen loads and land use. Not always there is accordance between chemical and biological indicators: no direct correspondence is evident between the $\mathrm{N}-\mathrm{NO}_{3}$ concentration in waters and benthic community. Its presence and abundance seems to be mostly correlated with the geomorphology, hydrology, riparian strips, etc. of the habitat than to the land use. Only the integration of chemical and biological
\end{abstract}

Correspondence: Dr. Francesca Ventura, Department of Agroenvironmental Science and Technology, University of Bologna, via Fanin 44, 40127 Bologna, Italy. Tel. +39.051.2096658 - Fax +39.051.2096241.

E-mail: francesca.ventura@unibo.it

Key words: ecological quality, chemical indicators, biological indicators, watersheds, agriculture.

Acknowledgements: the research Flussi idrici e di nutrienti dalla collina alla costa. Uno strumento per la valutazione della qualità di ecosistemi in EmiliaRomagna (FINQuER) was supported by the University of Bologna as strategical project.

Received for publication: 18 May 2011.

Accepted for publication: 16 November 2011.

○Copyright L. Pieri et al., 2011

Licensee PAGEPress, Italy

Italian Journal of Agronomy 2011; 6:e36

doi:10.4081/ija.2011.e36

This work is licensed under a Creative Commons Attribution NonCommercial 3.0 License (CC BY-NC 3.0). parameters allows a correct understanding of the state of health of water body and benthic communities.

\section{Introduction}

Agricultural lands are a major source of water pollutant (OECD, 2001). The latest data on the quality of European water resources highlight the detrimental impact of over-fertilization on the quality of surface waters at present (EEA, 2010), which can lead to eutrophication and offer significant risks on human health and aquatic ecosystems. In this context, the need for clear and accurate water quality determination in agricultural areas is vital as a reliable basis for any understanding of the relationship between land use and management and aquatic environmental impact.

The vulnerability of a specific area and the presence of a particular water habitat depend on its natural features (such as geology, climate, hydrology, soils, slope, hydrodynamism, presence of vegetated strips) and can be altered by pollution deriving from human activity such as agriculture.

Past studies indicate that there is a strong relationship between land use and water quality of both surface and ground water in the area (Zalidis et al., 2002; Tong and Chen, 2002) and changes in land use and management practices have considerable impact on water quality parameters. In particular, it is clear that watersheds with a large proportion of agricultural land tend to release greater amounts of nutrients to surface waters (Mason et al., 1990). To obtain a synthetic description of the ecological quality of a water body, two approaches are generally followed: the first regards the evaluation of chemicals residues and the second deals with the biological indicators.

The first approach consists in the direct or indirect determination of the most harmful chemical species. Among them, nitrogen (N), especially in the nitrate form, represents one of the most important factors in water quality degradation: through the nitrate directive (91/676/CEE), UE aims to reduce water pollution caused by nitrate losses from cultivated areas. In the so-called vulnerable zone there is a high risk of nitrate pollution and specific limits on fertilizer applications are set. The World Health Organization recommends not exceeding $50 \mathrm{mg} \mathrm{L}^{-1}$ of nitrate $\left(11.3 \mathrm{mg} \mathrm{N} \mathrm{L}^{-1}\right)$ in drinking water, for its elevate risk of generating diseases like methaemoglobinemia and stomach cancer (Merrington et al., 2002; Pavoni, 2003), while for ammonium, the national limit in Italy is $0.5 \mathrm{mg} \mathrm{L}^{-1}$ (D.Lgs. $31 / 2001$ ).

Data about $\mathrm{N}$ losses, as derived from the literature, are quite variable: in Italy, Pasti et al. (1995) found nitrate losses in drainage water between 20 and $27 \mathrm{~kg} \mathrm{~N} \mathrm{ha}^{-1} \mathrm{yr}^{-1}$; Bonaiti and Borin (2010) found in an experiment held in North-East of Italy nitrate losses ranging from 0.3 
to $24 \mathrm{~kg} \mathrm{ha}^{-1} \mathrm{y}^{-1}$ in open ditch drainage water and from 1.2 to $105 \mathrm{~kg}$ $\mathrm{ha}^{-1} \mathrm{y}^{-1}$ in subsurface drainage water. Casalì et al. (2008) in runoff water of two Spanish watersheds found nitrate losses ranging between 60 and $160 \mathrm{~kg} \mathrm{~N} \mathrm{ha}^{-1} \mathrm{yr}^{-1}$, while Owens (1994) indicated losses in drainage water ranging from 0.7 to $120 \mathrm{~kg} \mathrm{ha}^{-1} \mathrm{~N} \mathrm{yr}^{-1}$.

Next to the $\mathrm{N}-\mathrm{NO}_{3}$ water concentration, the $\mathrm{N}$ balance is another useful indicator of the risk posed to the environment from excessive nitrogen, deriving prevalently from arable lands. It also allows quantifying the relative importance of different sources of $\mathrm{N}$ inputs and outputs and evaluating the influence of soil use on the quality of surface water (Rossi Pisa et al., 1996; Gardi, 2001).

The second approach consists in the determination of the water quality by means of biological indicators, such as benthic fauna and the chlorophyll-a concentration (Buffagni et al., 2004; Dodds et al., 2002; Solimini et al., 2007). Benthic macroinvertebrates (insect, crustacean and shellfish populations) are good indicators because, thanks to their size, can be easily sampled and, being typically sedentary, are often affected by water quality. Furthermore, they include a broad range of taxonomic, functional and trophic groups with different tolerance to pollution, and are important components of both detritus and grazing food chains, transferring nutrients and toxicants to the rest of the system (Dauer, 1993). The presence and distribution of benthic macroinvertebrates can then provide information on ecosystem status, because their respond to habitat alteration with variation at community, population or genetic level (Chambers et al., 2006; Johnson, 1996). A high diversity of the benthic fauna usually indicates a good status of its habitats (EC, 2000). The chlorophyll-a concentration is another important biological indicator, evidencing the presence of phytoplankton (Solimini et al., 2007).

Both the described biological indicators are supposed to be tightly linked with chemical water quality. Nutrient loads (N and P) are considered the main cause of eutrophication (Brooks et al., 1997) and it is known that the dissolved inorganic $\mathrm{N}$ can be incorporated rapidly by phytoplankton and various opportunistic seaweeds, which respond with a massive growth. This process leads to a shift in the biological structure and, in severe cases, even to oxygen depletion, production of toxic substances (e.g. $\mathrm{NH}_{4}+\mathrm{H}_{2} \mathrm{~S}$ ) and the collapse of entire aquatic ecosystem (OECD, 1982).

Even if it seems that both benthic fauna and algal growth could provide information on the ecological status of surface waters (Ponti and Abbiati, 2004), the relationship is not so linear. The status of benthic fauna depends not only on the environmental quality, but also on the presence of intrinsic limiting factors, such as the hydrological characteristics of the water body. In a disturbed ecosystem a low number of species, the disappearance of sensitive species, the dominance of tolerant species and a change in the number of individual within the species are often observed (Duaer, 1993, Lardicci et al., 1993; Abbiati et al., 2010).

Finally, Parsons et al. (2004) and De Ventre et al. (2006) suggest that, being arable lands a diffuse source of pollution, the monitoring of water quality variables can be best approached in small sized watersheds instead of in large ones. In fact in large watersheds the pollutant transport processes entail a higher degree of complexity, thus failing to identify the nutrient source and the significant processes.

Therefore, in this study we examine three totally or partially cultivated small watersheds located in the Po valley, that is one of the regions in Europe suffering most from eutrophication (de Wit and Bendoricchio, 2001), with the purpose of: i) evaluating their ecological status, by means of chemical and biological indicators, over a 2-years period; ii) verifying the coherence among the diverse indicators; iii) identifying the relationships between land use, land management, geomorphology and water quality.

\section{Materials and Methods}

Water quantity (rainfall, influx and efflux) and quality (chemical and biological) were monitored in three agricultural watersheds located in Emilia Romagna region (Figure 1), in the 2007-2009 period. The region climate is temperate-Mediterranean (Köppen-Geiger classification), where the highest and lowest temperatures occur in July-August and December-January respectively, and the annual average precipitation is $750 \mathrm{~mm}$, concentrated in two major rainy seasons, autumn and spring.

All the watersheds are covered by cultivated or natural fields and are hydrologically isolated, so that they are suitable to study the problem of agriculture activity and water pollution (Pieri et al., 2011; Ventura et al., 2008).

The site 1 (197 ha) is located in Ozzano dell'Emilia (Bologna, Italy) on the first northern Apennines relief, and drained by the Centonara stream. Its elevation ranges between 84 and $354 \mathrm{~m}$ asl, with mean slope of $25-35 \%$ (15\% in cultivated area) (Table 1). Badlands are present on the $20 \%$ of the total area. The arable land constitutes about $25 \%$ of the total area, in part organically cultivated. Main crops are $40 \%$ alfalfa, $30 \%$ cereals (wheat, barley, sorghum) and 10\% industrial crop, especially sunflowers. The geomorphology of the site is characteristic of a torrential regime in low hill areas: dry in summer and full of water in winter. The area of investigation is at the downstream end of the basin, therefore the only source of water is meteoric, which drains into the soil. The hydrographic network is dendriform on the badlands; it is collected in a single course in the cultivated hills that eventually flows into the plain. The river bed has several jumps, even higher than 2 meters, and a thick riparian vegetation on both banks (Figure 1a).

The site 2 (750 ha) is located in Argelato (Bologna, Italy), in an intensively cultivated plain area, and drained by the Argelato channel (Table 1). The area is in plain, with elevation of $25 \mathrm{~m}$ asl. Main crops are $65 \%$ cereals, $15 \%$ leguminous and $13 \%$ industrial crops, mostly cultivated with conventional management. The channel collects only drainage water coming from the fields. The geomorphology of the site

Table 1. Watershed characteristics.

\begin{tabular}{|c|c|c|c|}
\hline Characteristics & $\begin{array}{c}\text { Site } 1 \\
\text { Centonara }\end{array}$ & $\begin{array}{l}\text { Watersheds } \\
\text { Site } 2 \\
\text { Argelato }\end{array}$ & $\begin{array}{c}\text { Site } 3 \\
\text { Valle Volta }\end{array}$ \\
\hline Surface (ha) & 197 & 750 & 1940 \\
\hline Arable land (\%) & 25 & 99 & 99 \\
\hline Mean slope & $\begin{array}{l}25-35 \% \text { total basin } \\
15 \% \text { arable lands }\end{array}$ & $1 \%$ & $<0.1 \%$ \\
\hline $\begin{array}{l}\text { Soil texture } \\
\text { (FAO classification) }\end{array}$ & Heterogeneous & $\begin{array}{l}\text { Clay-silt loam } \\
\text { Clay-silt }\end{array}$ & $\begin{array}{l}\text { Clay-loam } \\
\text { Clay-silt loam }\end{array}$ \\
\hline Soil organic matter (\% & 1.2 & 2.5 & 5 \\
\hline $\begin{array}{l}\text { Agriculture } \\
\text { management }\end{array}$ & $\begin{array}{l}\text { Partially } \\
\text { organic }\end{array}$ & $\begin{array}{c}\text { Mostly } \\
\text { conventional }\end{array}$ & $\begin{array}{c}\text { Mostly } \\
\text { integrated }\end{array}$ \\
\hline Drainage & No & No & $\begin{array}{c}45 \% \\
\text { tile-drained } \\
55 \% \\
\text { surface drained }\end{array}$ \\
\hline Irrigation & No & No & Yes \\
\hline $\begin{array}{l}\text { Riparian } \\
\text { vegetation }\end{array}$ & $\begin{array}{c}\text { Fully } \\
\text { developed }\end{array}$ & $\begin{array}{c}\text { Partially } \\
\text { developed }\end{array}$ & $\begin{array}{c}\text { Not } \\
\text { present }\end{array}$ \\
\hline Note & Presence of badlands & & $\begin{array}{l}\text { Watershed below } \\
\text { sea level; } \\
\text { nitrate vulnerable } \\
\text { zone }\end{array}$ \\
\hline
\end{tabular}


is that of a plain channel with just meteoric water supply. The result is that it is dry along the summer. The sampling occurs at the end of the basin. The riparian zone is spontaneous but not continuously presents (Figure 1b).

The site 3 (1940 ha), called Valle Volta, is located in an intensively cultivated area in the Ferrara plain (Ferrara, Italy), in a Nitrate Vulnerable Zone (Table 1). Its elevation is $3 \mathrm{~m}$ bsl. Main crops are $50 \%$ cereals (wheat and corn), 18\% alfalfa, $12 \%$ industrial crops (sugar beet, soybean) and $9 \%$ vegetables (tomatoes, watermelon, melon). Most of the crops are cultivated following the protocol for integrated agriculture (management with low chemical impact) and irrigated. Irrigation water derives from the Po di Volano river. About $45 \%$ of the agricultural soil is tile-drained and drainage water is collected in an artificial navigable channel and then pumped back in the river. The geomorphology of the site is that of a plain channel, apparently similar to site 2 , but significantly larger and never dry. This means that, unlike the sites 1 and 2 , this basin can be considered as an intermediate channel section between the head and the mouth of the water body. The riparian zone is almost non-existent because of cutting (Figure 1c).

Mean annual nitrogen fertilizations (5 last years) were $9 \mathrm{~kg} \mathrm{ha}^{-1}$ in site $1,100 \mathrm{~kg} \mathrm{ha}^{-1}$ in site 2 and $80 \mathrm{~kg} \mathrm{ha}^{-1}$ in site 3 . The most used fertilizers in all the watersheds were urea and ammonium nitrate. On average, nitrogen was applied twice or three times on herbaceous crops, during the growing season, especially in spring.

For this research, data about meteorological elements, land use and water flux were continuously recorded, while rainfall and surface water were periodically collected. Meteorological data were recorded in the site 1 thanks to an agrometeorological station recording air temperature and humidity, rainfall, solar radiation and wind speed; the site 2 was equipped with a wet and dry pluviometer (Micros), while in site 3

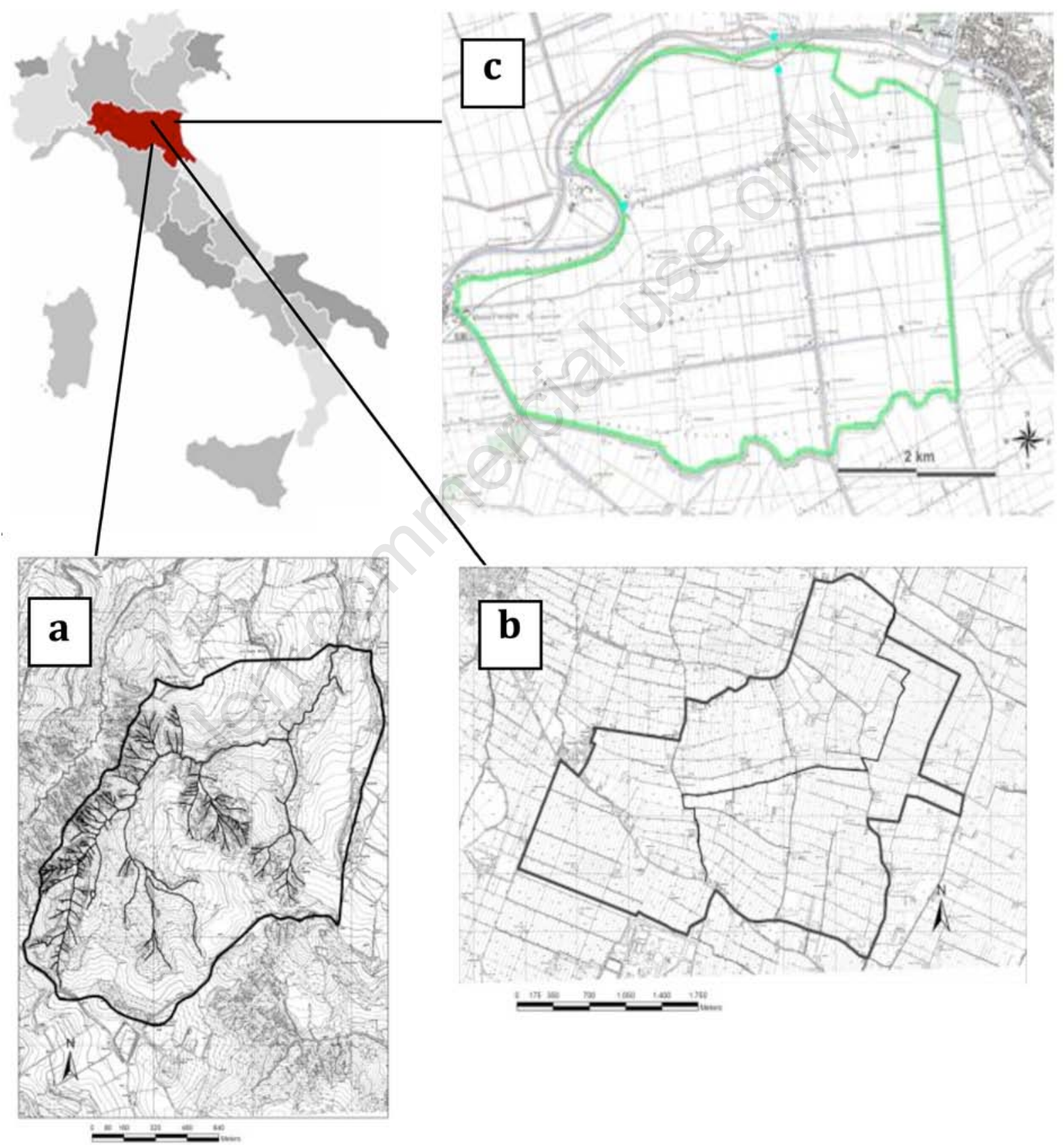

Figure 1. The three watersheds investigated for this study: a) Centonara $\left(44^{\circ} 27^{\prime} \mathrm{N}, 1^{\circ} 28^{\prime} \mathrm{E}\right)$; b) Argelato $\left(44^{\circ} 38^{\prime} \mathrm{N}, 11^{\circ} 20^{\prime} \mathrm{E}\right)$; c) Valle Volta $\left(44^{\circ} 48^{\prime} \mathrm{N}, 12^{\circ} 01^{\prime} \mathrm{E}\right)$. All are located in the Emilia Romagna region (see map of Italy). 
there was a pluviometer. Precipitations were sampled twice per month, or more frequently, depending on the frequency and intensity of rainfall events. Land use data were collected by ground surveys (GPS) and interpretation of aerial photographs in sites 1 and 2 , while in site 3 they were provided by the Regional Agency for financing in the agricultural sector (AGREA). In site 1 and 2 the water was continuously monitored by means of a sampling and measurement station (ISC0, 6700, Torino, Italy). The station is comprehensive of an automatic sampler that collects samples of water from the stream and pipes them into polypropylene bottles stored in a refrigerator (to avoid nitrate microbiological degradation). An ultrasonic sound waves module, fixed on the bottom of the canal, provides the measure of level and velocity of water. In site 3 the surface water was manually sampled twice per month in the outlet point of the watershed. Water influx and efflux were mechanically controlled, and water volumes were registered from the local water board (Secondo Circondario Polesine-San Giorgio; Ventura et al., 2008), which provided us the data. To determine the chemical water quality, all the 150 water samples ( 65 from the site 1,30 from the site 2 , and 55 from the site 3 ) were analyzed with an automatic instrument (AA3, Bran+Luebbe GmbH, Norderstedt, Germany) for the determination of nitrate-nitrogen (N-NO3) and ammonium-nitrogen ( $\mathrm{N}^{\left.-\mathrm{NH}_{4}\right)}$ concentration. For each basin, the $\mathrm{N}$ balance was calculated for two crop cycles (2007-2008 and 2008-2009), following the simplest deterministic approach of Howarth et al. (1996), which provides a static accounting of the input and output components, considering the main fluxes of materials entering and leaving the watershed. The balance, surplus or deficit, is a measure of the net depletion (output $>$ input) or enrichment (output < input) of the system (Watson and Atkinson, 1999; Oenema et al., 2003; Oenema and Heinen, 1999).

More precisely, the following equation was computed:

$\Delta \mathrm{N}=$ input components $\left(\mathrm{N}_{\mathrm{F}}+\mathrm{N}_{\mathrm{AD}}+\mathrm{N}_{\mathrm{SF}}\right)$ - output components $\left(\mathrm{N}_{\mathrm{PR}}+\right.$ $\mathrm{N}_{\mathrm{DW}}+\mathrm{N}_{\mathrm{D}}+\mathrm{N}_{\mathrm{V}}$ )

where:

$\Delta \mathrm{N}$, nitrogen variation;

$\mathrm{N}_{\mathrm{F}}$, inorganic and organic fertilization;

$\mathrm{N}_{\mathrm{AD}}$, atmospheric deposition;

$\mathrm{N}_{\mathrm{SF}}$, symbiotic $\mathrm{N}$ fixation;

$\mathrm{N}_{\mathrm{PR}}$, plant removal;

$\mathrm{N}_{\mathrm{DW}}$, losses in drainage water;

$\mathrm{N}_{\mathrm{D}}$, denitrification losses;

$\mathrm{N}_{\mathrm{V}}, \mathrm{NH}_{3}$ volatilization. All terms are in $\mathrm{kg} \mathrm{N} \mathrm{ha}^{-1} \mathrm{yr}^{-1}$.

$\mathrm{N}_{\mathrm{F}}$ was directly obtained by farmers' interviews. $\mathrm{N}_{\mathrm{AD}}$ and $\mathrm{N}_{\mathrm{DW}}$ were calculated from water volumes and nitrogen concentration, determined by analysis on rainfall and water samples (Pieri et al., 2009; Ventura et al., 2008). $\mathrm{N}_{\mathrm{SF}}$ was estimated through the model proposed by HøgenJensen et al. (2004). $\mathrm{N}_{\mathrm{PR}}$ estimates were based on data of crop yields, provided by farmers' interviews and on their $\mathrm{N}$ concentration obtained by regional databases (Regione Lombardia-PSR 2003; Regione Campania-DGR 2302/2003), and referred to the whole area. For $\mathrm{N}_{\mathrm{V}}$ and $\mathrm{N}_{\mathrm{D}}$ no direct measurements were made in situ and are presented only to show their relative importance to other terms of the balance. $\mathrm{N}_{\mathrm{V}}$ was quantified using empirical equations described in literature (Puckett $e t$ al. 1999; Isidoro et al. 2006), while $\mathrm{N}_{\mathrm{D}}$ values derived from experimental data obtained in regions close to our studied area (Gamba et al. 1998; Arcara et al. 1999). The trophic status was estimated by the determination of the chlorophyll-a concentration. Three replicate samples were taken randomly in April 2008 and April 2009. To measure chlorophyll-a, a volume of water from the surface, is filtered on cellulose filters (Millipore, pore size $0.45 \mu \mathrm{m}$ ). The chlorophyll-a in this material is then extracted with $90 \%$ acetone and spectrophotometrically analyzed according to Strickland and Parsons (1972). The biological quality was evaluated by macrobenthic assemblage composition and species diversity. For each basin and at two sampling dates (April 2008 and April 2009) and if water was present, three bottom samples were collected by a modified Eckman grab (area $15 \mathrm{~cm} \times 15 \mathrm{~cm})$. After a pre-sieving $(0.5$ $\mathrm{mm}$ mesh) in the field, samples were preserved using a buffered solution of $4 \%$ formaldehyde. Specimens were identified to the lowest possible taxonomic level, using a binocular microscope, and counted. Macrobenthic assemblages were analyzed in term of species abundance. Species richness (as number of species, S), Shannon index (H', logarithm base 2) and the corresponding evenness component (Pielou index, J) were calculated for each replicate sample (Krebs, 1989).

\section{Results}

\section{Meteorological and hydrological results}

Figure 2 shows the precipitation and the discharge during the studied period. The precipitation pattern of the three watersheds were sim-
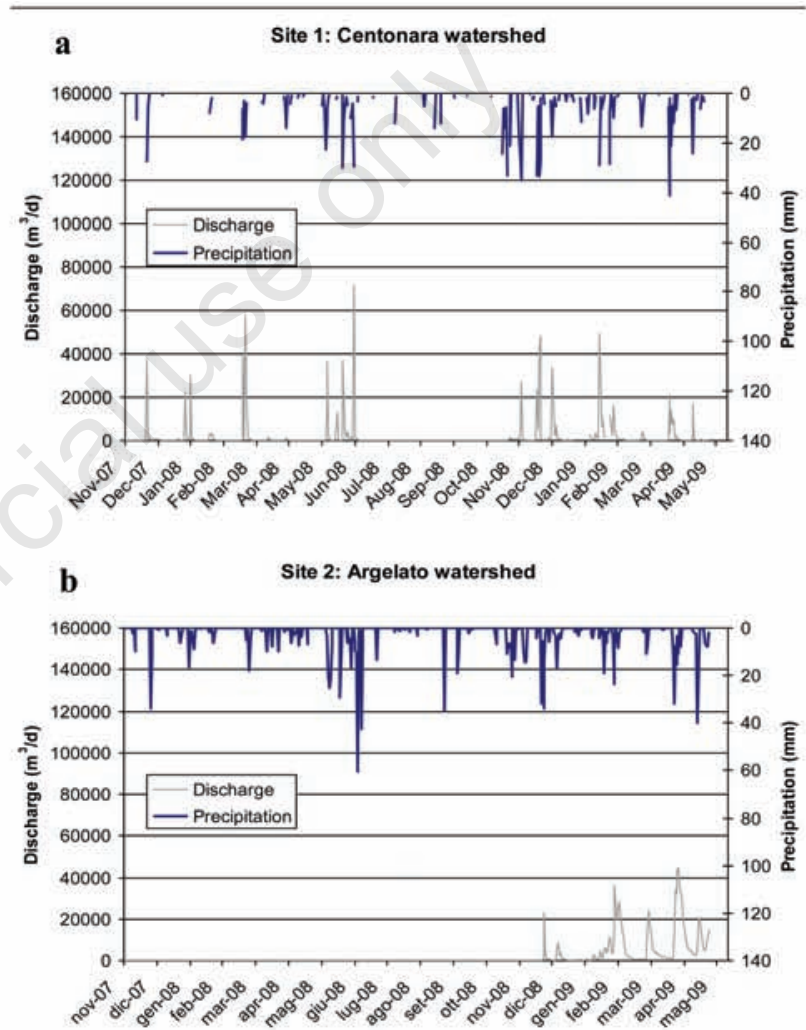

c Site 3: Valle Volta watershed

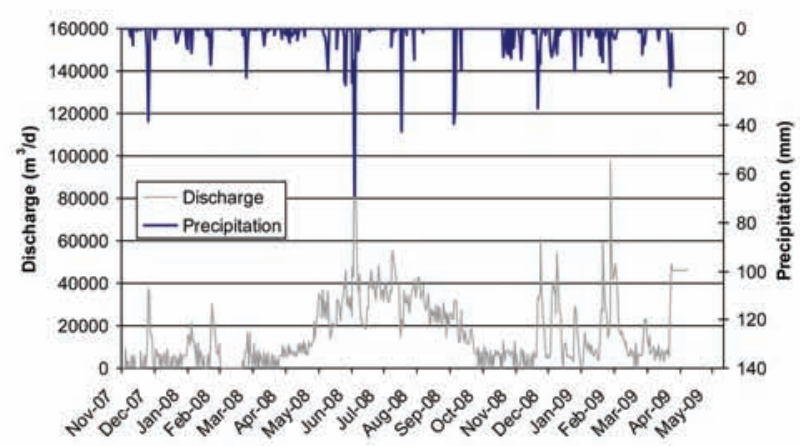

Figure 2. Precipitation and discharge recorded in the three watersheds: site 1 (Centonara, a), site 2 (Argelato, b) and site 3 (Valle Volta, c). 
ilar, with two main rainy seasons, autumn and spring, while the discharge was characterized by a different behaviors.

In site 1 (Figure 2a), the Centonara stream presented peaks of discharge consequently to long or intensive rain events. In particular, there was a correspondence between the rainfall peak and the maximum discharge after consecutive events with more than $20 \mathrm{~mm} / \mathrm{d}$. During the summer the stream was dry, due to the pluviometric regime and the elevate evapotranspiration during the summer. During the whole studied period, the amount of rainfall (P) was $1097 \mathrm{~mm}$, corresponding to a discharge (D) of $132.2 \mathrm{~mm}$. The mean discharge coefficient for the study period was 0.12 , same as the coefficient calculated for the year $2008\left(\mathrm{P}_{2008}=716 \mathrm{~mm} / \mathrm{y}, \mathrm{D}_{2008}=89 \mathrm{~mm} / \mathrm{y}\right)$.

In site 2 (Figure $2 \mathrm{~b}$ ), the total precipitation amount was $1210 \mathrm{~mm}$ for the whole period, with a discharge of $143 \mathrm{~mm}$. The channel was dry for a long period, probably because of a long dry season, during which the water-table level lowered. Discharge flow restarted after the beginning of the rainy period in November 2008 and continued in winter 2009, when several snow events occurred. Considering only the time when it was active, the discharge coefficient was equal to $0.34\left(\mathrm{P}_{11 / 29 / 08}\right.$ $\left.7 / 10 / 09=419 \mathrm{~mm}, \mathrm{D}_{11 / 29 / 08-7 / 10 / 09}=143 \mathrm{~mm}\right)$. This coefficient was typical for well drained basin in plain. In site 3 (Figure 2c), the total rainfall amount was $998 \mathrm{~mm}$ for the whole period, with a total discharge of $1155 \mathrm{~mm}$. Major discharges occurred in summer, when water is input into the channel from the Po di Volano river, to provide water for irrigation to the farmers. For this reason the discharge coefficient is not meaningful.
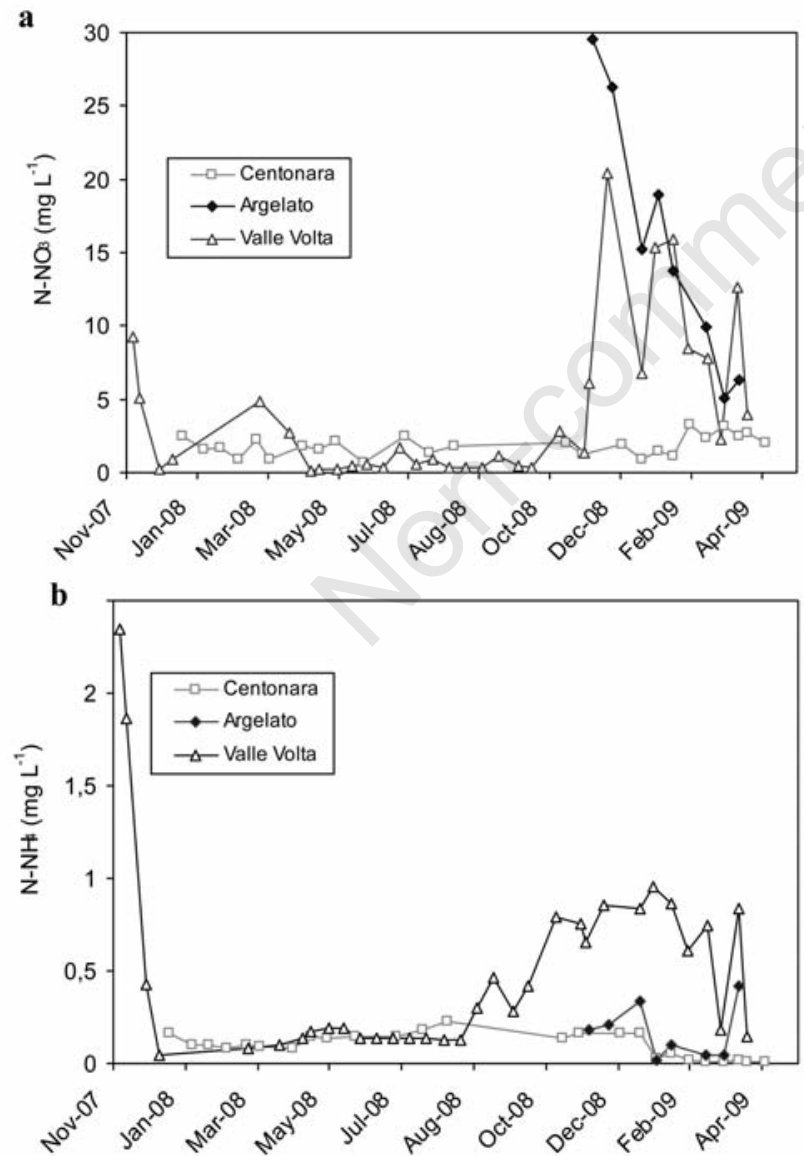

Figure 3 Nitrate (a) and ammonium (b) concentrations (mg L-1) in the drainage water of site 1 (Centonara, squares), site 2 (Argelato, circles) and site 3 (Valle Volta, triangles).

\section{Nitrate and ammonium concentration}

Figure 3 shows the trend of $\mathrm{N}-\mathrm{NO}_{3}$ and $\mathrm{N}-\mathrm{NH}_{4}$ concentrations in the drainage water of the three sites. As shown in Figure $3 \mathrm{a}$, site 1 displays a very low variability in $\mathrm{N}_{-} \mathrm{NO}_{3}$ concentrations during the whole year, with values being always below $3.2 \mathrm{mg} \mathrm{L}^{-1}$. In site 2 , the $\mathrm{N}^{-N_{3}}$ concentration presents the highest value in November $\left(30 \mathrm{mg} \mathrm{L}^{-1}\right)$ showing a decreasing trend till April 2009, when it reached $6 \mathrm{mg} \mathrm{L}^{-1}$. These values are above the UE limit for drinking water (11.3 $\left.\mathrm{mg} \mathrm{L}^{-1}\right)$ from October 2008 to January 2009. In site $3, \mathrm{~N}^{-\mathrm{NO}_{3}}$ concentration shows a more evident seasonal pattern: it presents low concentrations, close to zero, during the summer, with higher values in the other periods. Values exceed the UE limit (to a max of $20 \mathrm{mg} \mathrm{L}^{-1}$ ) only in 4 out a total of 33 samples, during winter and spring. As shown in Figure $3 \mathrm{~b}$, in both site 1 and site $2, \mathrm{~N}^{-\mathrm{NH}_{4}}$ concentration is about one order of magnitude lower than $\mathrm{N}^{-\mathrm{NO}_{3}}$ and presents the highest values during the summer ( $0.2 \mathrm{mg} \mathrm{L}^{-1}$ and $0.4 \mathrm{mg} \mathrm{L}^{-1}$ in Centonara and Argelato, respectively). In site 3 , the $\mathrm{N}-\mathrm{NH} 4$ concentration trend is similar to that of $\mathrm{N}_{-} \mathrm{NO}_{3}$ and above the limit of $0.5 \mathrm{mg} \mathrm{L}^{-1}$, recommended by the Italian law (D.Lgs. 31/2001), during autumn and winter. Moreover, ammonium in site 3 is higher than in the other 2 sites. This may be due to the diverse sampling technique: in sites 1 and 2 the bottles storing the water samples are open and left in the fridge some days before being analyzed, so they can loose some ammonium per volatilization. Water in site 3 is instead manually sampled and immediately closed in the bottle. Figure 4 shows the $\mathrm{N}$ load, obtained multiplying
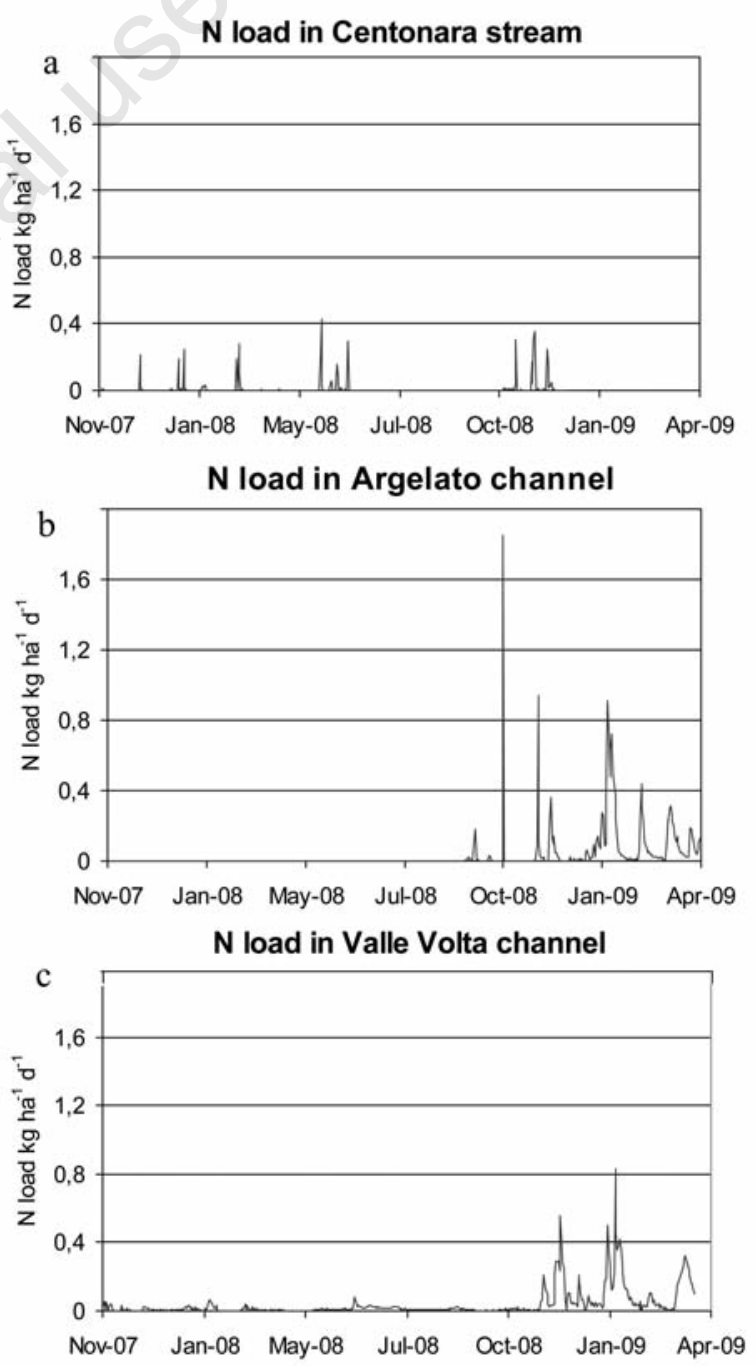

Figure 4. Nitrogen loads (kg ha-1) in site 1 (Centonara, a), site 2 (Argelato, b) and site 3 (Valle Volta, c). 
Table 2. Nitrogen balance $\left(\mathrm{kg} \mathrm{ha}^{-1}\right)$ in the three watersheds for the two crop cycles: 2007-08, 2008-09.

\begin{tabular}{|c|c|c|c|c|c|c|}
\hline & \multicolumn{4}{|c|}{$\begin{array}{c}\text { Watershed } \\
\text { Site } 2 \text { - Argelato }\end{array}$} & \multicolumn{2}{|c|}{ Site 3 - Valle Volta } \\
\hline & 2007-08 & 2008-09 & 2007-08 & 2008-09 & 2007-08 & 2008-09 \\
\hline \multicolumn{7}{|l|}{ Input } \\
\hline Fertilization & 11.3 & 11.6 & 106.4 & 105.7 & 79.3 & 78.5 \\
\hline Biological fixation & 15.8 & 13.9 & 27.2 & 31.0 & 41.5 & 126.0 \\
\hline Atmospheric deposition & 9.9 & 8.1 & 12.4 & 12.5 & 7.7 & 8.8 \\
\hline Irrigation & 0 & 0 & 0 & 0 & 4.8 & 2.3 \\
\hline Total & 37.0 & 33.6 & 146.0 & 149.2 & 134.0 & 216.4 \\
\hline \multicolumn{7}{|l|}{ Output } \\
\hline Plant removal & 26.9 & 27.0 & 118.0 & 97.2 & 128.3 & 213.5 \\
\hline Discharge & 3.0 & 4.5 & 0 & 3.5 & 1.8 & 1.8 \\
\hline Denitrification & 0.5 & 0.5 & 4.3 & 4.2 & 1.6 & 1.6 \\
\hline Volatilization & 1.1 & 1.2 & 10.6 & 10.6 & 2.7 & 3.8 \\
\hline Total & 31.5 & 33.1 & 132.9 & 115.5 & 134.4 & 220.7 \\
\hline \multicolumn{7}{|l|}{ Balance } \\
\hline Input - output & 5.5 & 0.5 & 13.1 & 33.7 & -0.4 & -4.3 \\
\hline
\end{tabular}

the total $\mathrm{N}$ concentration by the discharge rate value. The highest daily $\mathrm{N}$ load $\left(\mathrm{kg} \mathrm{ha}^{-1} \mathrm{day}^{-1}\right)$ was in the Argelato channel, with a peak of $1.8 \mathrm{~kg} \mathrm{ha}^{-1}$ day $^{-1}$, while in Centonara stream N was most of the time close to $0.0 \mathrm{~kg} \mathrm{ha}^{-1}$ day $^{-1}$ and it has almost never exceeded $0.4 \mathrm{~kg} \mathrm{ha}^{-1}$ day $^{-1}$ (Figure $4 \mathrm{a}, \mathrm{b}$ ). Valle Volta channel had intermediate values, with a maximum of $0.8 \mathrm{~kg} \mathrm{ha}^{-1}$ day $^{-1}$ (Figure 4c).

\section{Nitrogen balance}

The nitrogen balance for the three watersheds is summarized in Table 2. For each watershed, there were no significant differences (ttest) between the two years, due to similar management: in site 1 and site 3 , balances were almost closed, while, in site 2 , inputs exceeded outputs, by 13.1 and $33.7 \mathrm{~kg} \mathrm{ha}^{-1}$, respectively in 2007-08 and 2008-09.

The balance differences among watersheds were due to land use, which determines input and output amounts. In particular, the site 1, being only partially cultivated, presented balance terms very different from the other two sites. Its major input was the biological fixation (41$43 \%$ of the total input) due to the alfalfa cultivation, that was the most cultivated crop (17\% of the SAU), while $\mathrm{N}$ fertilization equal to $9.4 \mathrm{~kg}$ $\mathrm{ha}^{-1}$, was concentrated in a limited part of the basin on no-leguminous crops. Fertilization amount was comparable to the atmospheric deposition $\left(9 \mathrm{~kg} \mathrm{ha}^{-1}\right)$. In sites 2 and 3 , major inputs sources were fertilizers, about $75 \%$ and $51-36 \%$ of total input respectively, and biological fixation, about $20 \%$ and $30-60 \%$ of total input respectively. Atmospheric depositions were similar everywhere, ranging between 7.7 and $12.5 \mathrm{~kg}$ $\mathrm{ha}^{-1}$ and differences between the watersheds were mainly due to the diverse rainfall regimes.

The yearly rotations, in particular the presence of leguminous crops, lead to a diverse proportion between fertilization and biological fixation between the two years. On the hectare basis, the major fertilizer input occurred with corn, $\left(160-250 \mathrm{~kg} \mathrm{~N} \mathrm{ha}^{-1}\right)$. Corn accounted for the $70 \%$ and $80 \%$ (mean of the two years) of the total fertilizers input, in site 2 and site 3 , respectively. In the three sites, major output was represented by plant removal, which due to different land use, varied among watersheds.

As seen previously, $\mathrm{N}$ losses by efflux water in all the watersheds were limited, ranging between 1.8 and $4.5 \mathrm{~kg} \mathrm{ha}^{-1}$ (apart from Argelato 2008 , when the channel was totally dry). Nitrate losses $\left(\mathrm{N}_{\mathrm{DW}}\right)$ accounted for $8-13 \%$ of the total input in site 1 , while in site 2 and site 3 it ranged from 0 to $2 \%$. Considering only fertilization input $\left(\mathrm{N}_{\mathrm{F}}\right)$, they accounted for $27-39 \%$ in site 1 and $2-3 \%$ in site 2 and site 3 .
Table 3. Chlorophyll-a (Chl.) concentration ( $\mu \mathrm{g} \mathrm{L-1)}$ in the drainage water of the three sites in spring 2008 and 2009. Data represent the average \pm s.e.

\begin{tabular}{lcc} 
& $\begin{array}{c}\text { April 2008 } \\
\text { Chlorophyll-a } \\
(\mu g \text { Chl. L }\end{array}$ & $\begin{array}{c}\text { April 2009 } \\
\text { Chlorophyll-a } \\
(\mu g \text { Chl. L-1) }\end{array}$ \\
Site 1 - Centonara & 0.4 & $0.5 \pm 0.3$ \\
Site 2 - Argelato & Data not available & $119 \pm 6$ \\
\hline Site 3 - Valle Volta & 568 & $214 \pm 10$ \\
\hline
\end{tabular}

\section{Trophic status and benthic indexes}

Data referring to the trophic status are shown in Table 3 . In site 2, the channel was dry in April 2008 and no water or bottom sample was collected. In the rivers and in the channels of the Po valley, chlorophylla concentration follows a seasonal trend showing the highest peaks during spring.

Very low chlorophyll-a concentrations were found in site $1(<1 \mu \mathrm{g} / \mathrm{L})$ in both years, while in site 2 , in the single sampling performed on April 2009 , a value of $119 \mu \mathrm{g} \mathrm{L}^{-1}$ was found. In site 3 a very high chlorophylla value of above $500 \mu \mathrm{g} \mathrm{L}^{-1}$ was measured in 2008 , although a different sampling performed four days later evidenced that this amount was reduced to $81 \mu \mathrm{g} \mathrm{l}^{-1}$ (data not shown); a high value of $214 \mu \mathrm{g} \mathrm{L} \mathrm{L}^{-1}$ was obtained also the following year (April 2009). A microscope microalgae observation evidenced that autotrophic organisms were dominated by Euglenophyceae.

Overall, macrobenthic assemblages were composed by only 8 taxa (Table 4). In particular, samples from site 1 , showed only few individuals belonging to Oligochetae family and to the genus Theodoxus, a small freshwater snail. Oligochaetes and larvae of chironomid were the most abundant taxa at sites 2 and 3 , while the crustaceans Gammaridea were present only at site 3 . Site 1 presented the lowest species richness (S, Figure 5). Site 2 and 3 had the richest macrobenthic assemblages in term of number of taxa. Site 2, sampled only in 2009 , showed the highest species diversity (H') and evenness (J). The disproportionate increase of oligochaetes in site 3 between 2008 and 2009 was responsible to the corresponding decline of species diversity and evenness at this site. 
Table 4. Benthic data (ind. sample ${ }^{-1}$ ) of the three sites.

\begin{tabular}{|c|c|c|c|c|c|c|c|c|c|c|}
\hline Site & Year & Repl. & $\begin{array}{c}\text { Oligochetae } \\
\text { sp. } 1\end{array}$ & $\begin{array}{c}\text { Oligochetae } \\
\text { sp. } 2\end{array}$ & $\begin{array}{c}\text { Oligochetae } \\
\text { sp. } 3\end{array}$ & $\begin{array}{c}\text { Theodoxus } \\
\text { sp. }\end{array}$ & Gammaridea & Notonecta & Chirnomidae & $\begin{array}{c}\text { Chironomus } \\
\text { salinarius }\end{array}$ \\
\hline \multirow{6}{*}{$\begin{array}{l}\text { Site } 1 \text { - } \\
\text { Centonara }\end{array}$} & \multirow[t]{3}{*}{2008} & $\mathrm{a}$ & 0 & 0 & 0 & 0 & 0 & 0 & 0 & 0 \\
\hline & & b & 0 & 0 & 0 & 0 & 0 & 0 & 0 & 0 \\
\hline & & $\mathrm{c}$ & 2 & 0 & 0 & 0 & 0 & 0 & 0 & 0 \\
\hline & \multirow[t]{3}{*}{2009} & $a$ & 0 & 0 & 0 & 0 & 0 & 0 & 0 & 0 \\
\hline & & $\mathrm{b}$ & 0 & 0 & 0 & 1 & 0 & 0 & 0 & 0 \\
\hline & & c & 1 & 0 & 0 & 0 & 0 & 0 & 0 & 0 \\
\hline \multirow{3}{*}{$\begin{array}{l}\text { Site } 2 \text { - } \\
\text { Argelato }\end{array}$} & \multirow[t]{3}{*}{2009} & $a$ & 0 & 7 & 10 & 0 & 0 & 0 & 3 & 0 \\
\hline & & b & 0 & 14 & 10 & 0 & 0 & 0 & 4 & 0 \\
\hline & & C & 0 & 12 & 8 & 0 & 0 & 0 & 6 & 0 \\
\hline \multirow{6}{*}{$\begin{array}{l}\text { Site } 3 \text { - } \\
\text { Valle Volta }\end{array}$} & \multirow[t]{3}{*}{2008} & $\mathrm{a}$ & 18 & 0 & 0 & 0 & 1 & 0 & 0 & 4 \\
\hline & & $\mathrm{b}$ & 0 & 0 & 0 & 0 & 10 & 2 & 0 & 7 \\
\hline & & $\mathrm{C}$ & 0 & 0 & 0 & 0 & 0 & 0 & 0 & 7 \\
\hline & \multirow[t]{3}{*}{2009} & $\mathrm{a}$ & 92 & 0 & 0 & 0 & 1 & 0 & 0 & 8 \\
\hline & & $\mathrm{b}$ & 175 & 0 & 0 & 0 & 3 & 0 & 0 & 12 \\
\hline & & $c$ & 124 & 0 & 0 & 0 & 5 & 0 & 0 & 9 \\
\hline
\end{tabular}

\section{Discussion}

Chemical indicators ( $\mathrm{N}-\mathrm{NO}_{3}$ and $\mathrm{N}-\mathrm{NH}_{4}$ concentration, $\mathrm{N}$ balance), trophic status (chlorophyll-a concentration) and benthic population indexes are all useful elements to characterize the ecological status of rivers in areas heavily agricultural. Together, they should provide an overview of the water quality, which is supposed to be strictly related to the land use and the management, but their relationships are not always easy to predict.

Chemical indicators ( $\mathrm{N}-\mathrm{NO}_{3}$ concentration and $\mathrm{N}$ balance) are mostly in accordance, and can be explained by the different land use and agricultural management of the three watersheds. It is clear that watersheds with large and intensive arable land areas tend to release greater amounts of nitrogen to surface waters.

In site 1 the arable area is small (about $30 \%$ of the total) and partially cultivated by organic management. $\mathrm{N}$ in excess is probably absorbed by spontaneous vegetation, which acts as buffer zone and limits the $\mathrm{N}$ $\mathrm{NO}_{3}$ contamination of the Centonara stream. In site 2, the total area is intensively cultivated, mainly by conventional management. The result is an elevate $\mathrm{N}-\mathrm{NO}_{3}$ concentration in drainage water, in some periods above the UE limit for drinking water. In site 3, where the watershed is totally cultivated, mostly with integrated management, the $\mathrm{N}-\mathrm{NO}_{3}$ concentration is usually lower than the UE limit.

The Figure 3a highlights how the nitrogen cycle results to be strongly influenced by land use, crop managements (Chen and Driscoll, 2009), and meteorological condition. Channels draining large agricultural lands (site 2 and site 3 ) displayed a seasonal variability not present in site 1 , suggesting that agricultural activity greatly alters seasonal patterns in $\mathrm{N}$ cycling and loss.

In intensively managed agricultural watersheds (site 2 and site 3 ), the highest $\mathrm{N}-\mathrm{NO}_{3}$ concentrations were always recorded in autumnwinter, when rainfalls were abundant and mineral $\mathrm{N}$, residual from fertilization or deriving from the mineralization of soil organic matter, is available in soil. In spring-summer, growing crops adsorb nitrogen from the soil at highest rates and help maintaining a low risk of $\mathrm{N}$ leaching.

The highest $\mathrm{N}-\mathrm{NH}_{4}$ values in Valle Volta watershed (Figure $3 \mathrm{~b}$ ) during the late summer are probably due to the high mean temperatures, which increase the mineralization of soil organic $\mathrm{N}$, while the winter peak in site 3 may be due to a limited nitrification in soil under cold temperature. Moreover, the highest ammonium values in site 3 may be due to the channel size: the depth of the water favors anoxic condition, which determines the $\mathrm{NH}_{4}+$ formation, and the manual sampling helps
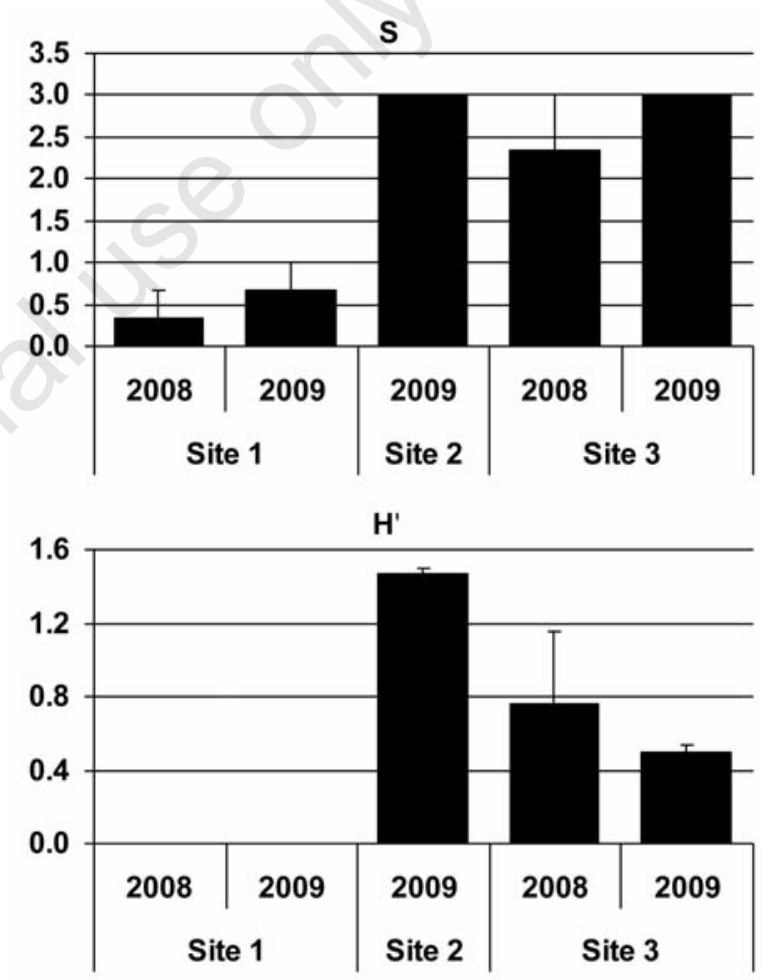

$\mathbf{J}$

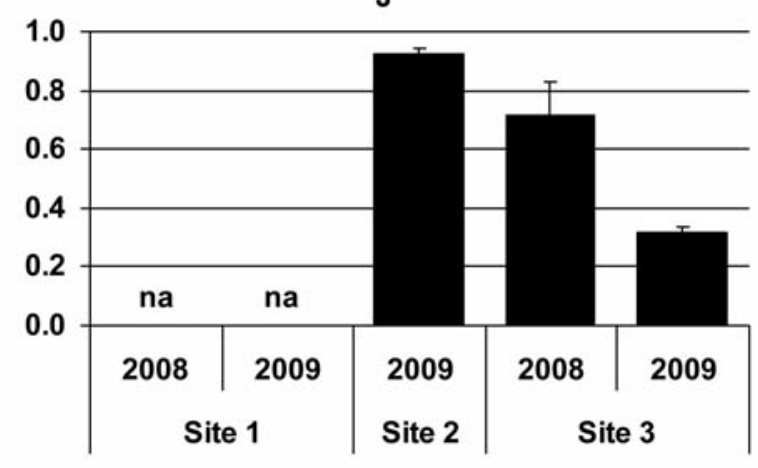

Figure 5. Species diversity indexes: species richness (S), Shannon's diversity $\left(H^{\prime}\right)$, Pielou's evenness $(\mathrm{J})$. Error bars represent the standard error. 
keeping high $\mathrm{N}-\mathrm{NH}_{4}$ levels, reducing volatilization.

The $\mathrm{N}$ balances calculated for the three watersheds further confirm the relationship between land use and $\mathrm{N}$ losses in discharge water: in sites 1 and 3 , total $\mathrm{N}$ outputs and inputs are similar and the balance is next to zero. Consequently, little $\mathrm{N}$ losses occur in the draining water. In these watersheds, crop management and especially $\mathrm{N}$ fertilization techniques, has reached good levels of ecological sustainability. In site 2 , the elevate $\mathrm{N}$ fertilizations $\left(>100 \mathrm{~kg} \mathrm{ha}^{-1}\right.$ ) are the main cause of high $\mathrm{N}$ surplus, which determined a higher risk of water contamination.

Although caution should be used in comparing literature results relative to sites with different pedo-climatic conditions, the $\mathrm{N}$ balances of the three watersheds are all significantly lower than others found in agricultural watershed in Europe and USA, which report surpluses ranging between 30 and $117 \mathrm{~kg} \mathrm{ha}^{-1}$ (Isidoro et al., 2006; Bechmann et al., 1998; David et al., 1997). Moreover, the $\mathrm{N}$ balance for the three sites is always lower than the national $\mathrm{N}$ balance calculated for Italy for the year $2000\left(37 \mathrm{~kg} \mathrm{ha}^{-1}\right)$ (EEA, 2005).

The chlorophyll-a concentration in discharge waters might depends on the nitrogen loads: in site 1, low nitrogen concentrations corresponded to low chlorophyll-a concentrations, while in sites 2 and 3, high chlorophyll-a concentrations were found in correspondence of elevated $\mathrm{N}-\mathrm{NO}_{3}$ concentrations. Since the microscope observations evidenced that autotrophic organisms in the water samples were dominated by Euglenophyceae, which are known to prefer environment rich in decaying organic matter, it cannot be excluded that organic $\mathrm{N}$ could also sustain the observed spring blooms. The chlorophyll-a threshold limit to define an environment as eutrophic is set by the local environmental agency at $10 \mu \mathrm{g} \mathrm{L}^{-1}$ (ARPA-Emilia Romagna); higher values evidence an anomalous microalgae bloom and are indicative of eutrophic water conditions. Site 2 and site 3 therefore present an elevate risk of eutrophication and lower ecological water quality in comparison with site 1.

No direct relationships were evidenced between macrobenthic species diversity and land use. The benthic populations of the three watersheds seem in fact to reflect more the geomorphology of their habitat than land use. The hydrodynamism of the Centonara stream, characterized by high discharge during the spring and autumn, dryness during the summer, maximum velocity $1.8 \mathrm{~m} \mathrm{~s}^{-1}$ and water height from 5 to $50 \mathrm{~cm}$, limits the survival of the aquatic species and consequently the number of taxa population. In such variable conditions, only few ephemeral aquatic life forms can occasionally populate the stream bottom. On the other hand, the slow water flux that characterizes channels in site 2 and site 3 favors the persistent benthic assemblages and relatively high species diversity. This is particularly evident in site 3 , where freshwater is available all over the year. Furthermore, in sites 1 and 2 the prolonged dry periods which occurred in summer, have probably destroyed the whole aquatic benthic community. The re-colonization of the channel may have occurred in site 2 because of the connection with the main river, which represents a reservoir for benthic species, thanks to pioneer and drought-resistant species such as the Theodoxus snail (Zettler et al., 2004). On the contrary, the hilly geomorphology of site 1 probably contrasted the re-colonization of the stream.

In site 3, the particular hydro-morphological conditions of the channel (slow water speed, water availability during the whole year) and to the absence of intrinsic limits allow an easier interpretation of the results, and it is possible to find a relationship between chemical and biological indicators. The relatively high benthic species diversity found in this site could be attributed to low chemical pollution. For example, the presence of the Gammaridea crustaceans, which is poorly resistant to nitrogen pollution (Alonso and Camargo, 2004), indicates a good water quality, while the insects of the genus Notonecta, which is a macropredator (Bernhardt, 1988), evidences the presence of a stable population.
Finally, results show that the presence of pollutants influences the survival and the abundance of benthic species, determining more or less marked changes in the assemblages' composition. However, in case of intrinsic limiting conditions of natural or anthropic origins in a water bodies, the absence of benthic fauna could not be sufficient to indicate the presence of water pollution. In similar situation, the biological indicators alone could not provide a correct and synthetic evaluation of the effective ecological quality, or rather, it can be discriminatory if so (developed biological community), but not significant if not (absence of population).

\section{Conclusions}

Results from the three agricultural watersheds point out that:

- chemical parameters characterize water quality, in terms of pollutant contamination, and allow the comprehension of their management efficiency. In fact there is a relationship between the chemical indicators (nitrate concentration and $\mathrm{N}$ balance) and land use (coverage and management).

- chlorophyll-a concentration depends on $\mathrm{N}$ loads and generally its value is correlated with the $\mathrm{N}$ concentration in water;

- the knowledge of the chemical water quality of a water body not always provides information on the aquatic population health. A low biodiversity could be due both to the presence of chemical contamination or to limiting conditions of the system (e.g. water stress, lack of riparian vegetation, steepness of the edge, homogeneity of the substrate);

- in-depth knowledge of the area is necessary for a correct interpretation of the results and help to understand if both chemical and biological indexes are needed. Often, the site geomorphology is scarcely considered by both scientific and political institutions, but this study confirms its importance, as suggested also by Nardini et al. (2008).

- a correct comparison of diverse sites using the species diversity indexes is possible only if the area has similar geomorphology;

- only the integration of analysis of the benthic population with fluxes of nutrients and water chemical investigation can provide a complete description of the quality of the aquatic ecosystem, but in absence of intrinsic limiting conditions of natural or anthropic water body, the biological indicators alone could provide a correct and synthetic evaluation of the effective ecological quality.

\section{References}

Abbiati M, Mistri M, Bartoli M, Ceccherelli VU, Colangelo MA, Ferrari CR, Giordani R, Munari C, Nizzoli D, Ponti M, Rossi R, Viaroli P, 2010. Trade-off between conservation and exploitation of the transitional water ecosystems of the northern Adriatic Sea. Chem. Ecol. 26:105-119.

Alonso A, Camargo JA, 2004. Toxic effects of unionized ammonia on survival and feeling activity of the freshwater amphipod Eulimnogammarus toletanus (Gammaridae, Crustacea). B. Environ. Contam. Tox. 72:1052-1058.

Arcara PG, Gamba C, Bidini D, Marchetti R, 1999. The effect of urea and pig slurry fertilization on denitrification, direct nitrous oxide emission, volatile fatty acids, water-soluble carbon and anthrone-reactive carbon in maize-cropped soil from the Po plain (Modena, Italy). Biol. Fert. Soils. 29:270-276.

ARPA, Emilia Romagna. Accessed on: 13 October 2011. Available from: http:/www.arpa.emr.it/glossario.asp?idlivello $=530$ 
Bechmann M, Eggestad HO, Vagstad N, 1998. Nitrogen balance and leaching in four agricultural catchments in southern Norway. Environ. Pollut. 102:493-499.

Bernhardt KG, 1988. The ecology and distribution of the Notonecta species (Notonectidae, Heteroptera) in the Ems and Osnabrueck area. Osnabruecker naturwissenschaftliche Mitteilungen 14:85-90.

Bonaiti G, Borin M, 2010. Efficiency of controlled drainage and subirrigation in reducing nitrogen losses from agricultural fields. Agr. Water Manage. 9:343-352.

Brooks KN, Folliott PF, Gregersen HM, DeBano LF, 1997. Hydrology and the Management of Watersheds. 2nd rev. ed. Iowa State University Press, Ames, IA, USA.

Buffagni A, Erba S, Cazzola M, Kemp JL, 2004. The AQEM multimetric system for the southern Italian Apennines: assessing the impact of water quality and habitat degradation on pool macroinvertebrates in Mediterranean rivers. Hydrobiologia 516:313-329.

Casalí J, Gastesi R, Álvarez-Mozos J, De Santisteban LM, Del Valle de Lersundi J, Giménez R, Larrañaga A. Goñi M, Agirre U, Campo MA, López JJ, Donezar M, 2008. Runoff, erosion, and water quality of agricultural watersheds in central Navarre (Spain). Agr. Water Manage. 95:1111-1128.

Dauer DM, 1993. Biological criteria, environmental health and estuarine macrobenthic community structure. Mar. Pollut. Bull. 26:249-257.

David MB, Gentry LE, Kovacic DA, Smith KM, 1997. Nitrogen balance next term in and export from an agricultural watershed. J. Environ. Qual. 26:1038-1048.

De Vente J, Poesen J, Bazzoffi P, Van Rompaey A, Verstraeten G, 2006. Predicting catchment sediment yield in Mediterranean environments: the important of sediment sources and connectivity in Italian drainage basins. Earth Surf. Proc. Land. 31:1017-1034.

de Wit M, Bendoricchio G, 2001. Nutrient fluxes in the Po basin. Sci. Total Environ. 273:147-161.

Dodds WK, Smith VH, Lohman K, 2002. Nitrogen and phosphorus relationships to benthic algal biomass in temperate streams. Can. J. Fish. Aquat. Sci. 59:865-874.

European Commission, 2000. Directive of the European Parliament and of the Council of 23 October 2000 establishing a framework for Community action in the field of water policy, 2000/60/EC. In: Official Journal, L 327, 22/12/2000, pp 1-72.

European Environmental Agency, 2005. The European Environmental State and Outlook 2005. Accessed on: 13 October 2011. Available from: http://www.eea.europa.eu/data-and-maps/indicators/grossnutrient-balance-1/gross-nutrient-balance-assessment-published

European Environmental Agency, 2010. The European Environmental State and Outlook 2010. Accessed on: 13 October 2011. Available from: http://www.eea.europa.eu/soer/europe

Gamba C, Arcara PG, Giordani G, Guermandi M, 1998. Influence of manure and cow slurry fertilizers on gaseous losses (N20) in maize cultivated plots on the Po river plain (Bologna, Italy). Agr. Med. 128:157-164.

Gardi C, 2001. Land use, agronomic management and water quality in a small Northern Italian watershed. Agr. Ecosyst. Environ. 87:1-12.

Hoøgh-Jensen H, Loges R, Jørgensen FV, Vinther FP, Jensen ES, 2004. An empirical model for quantification of symbiotic nitrogen fixation in grass-clover mixtures. Agr. Syst. 82:181-194.

Isidoro D, Quilez D, Aragues R, 2006. Environmental impact of irrigation in La Violada District (Spain): II nitrogen fertilization and nitrate export patterns in drainage water. J. Environ. Qual. 35:776-785.

Johnson RK, 1996. The indicator concept in freshwater biomonitoring In: P.S. Cranston (ed.) Chironomids: From Genes to Ecosystems. CSIR0 Publ., East Melbourne, Australia, pp 11-27.

Krebs CJ, 1989. Ecological Methodology. Harper and Row Publ., New York, NY, USA.

Lardicci C, Abbiati M, Crema R, Morri C, Bianchi CN, Castelli A, 1993.
The distribution of polycaetes along an environmental gradient, an example from the Orbetello lagoon, Italy. Mar. Ecol.-Prog. Ser. 14: $35-52$.

Mason JW, Wegner GD, Quinn GI, Lange EL, 1990. Nutrient loss via groundwater discharge from small watersheds in southwestern and south central Wisconsin. J. Soil Water Conserv. 45:327-331.

Merrington G, Winder L, Parkinson R, Redman M, 2002. Agricultural Pollution: Environmental Problems and Practical Solutions. Spon Press, London, UK.

Nardini A, Sansoni G, Schipani I, Conte G, Goltara A, Boz B, Bizzi S, Palazzo A, Monaci M, 2008. Problemi e limiti della Direttiva Quadro sulle Acque. Una proposta integrativa: FLEA (FLuvial Ecosystem Assessment). Biologia Ambientale 22:3-18.

OECD, 1982 Eutrophication of Waters: Monitoring, Assessment and Control. OECD Publ., Washington, DC, USA.

OECD, 2001. Environmental Indicators for Agriculture; Methods and Results, vol. 3. Accessed on: 13 October 2011. Available from: http:/www.oecd.org/dataoecd/24/35/40680869.pdf

OEDC/EUROSTAT, 2003. Gross Nitrogen Balances. Handbook. December 2003. Accessed on: 13 October 2011. Available from: http://www.eea.europa.eu/dataand-maps/indicators/gross-nutrientbalance-1

Oenema 0, Heinen M, 1999. Uncertainties in nutrient budget due to biases and errors. In: E.M.A. Smaling, 0. Oenema and L.O. Fresco (eds.) Nutrient Disequilibria in Agroecosystems: Concepts and Case Studies. CAB Int., Wallingford, UK, pp 75-97.

Oenema 0, Kros H, De Vries W, 2003. Approaches and uncertainties in nutrients budgets: implications for nutrient management and environmental policies. Eur. J. Agron. 20:3-16.

Osborne LL, Wiley MJ, 1988. Empirical relationships between land use/cover and stream water quality in an agricultural watershed. J. Environ. Manage. 26:9-27.

Owens LB, 1994. Impacts of N management on water quality. In: R. Lal and B.A. Stewart (eds.) Soil Process and Water Quality (Advances in Soil Sciences). Lewis Publ., Boca Raton, FL, USA, pp 137-162.

Parsons AJ, Wainwright J, Powell DM, Kaduk J, Brazier RE, 2004. A conceptual model for determining soil erosion by water. Earth Surf. Proc. Land. 29:1293-1302.

Pasti C, Montagner 0, Furlan L, 1995. Giudizio positivo sulle acque di scolo agricole. Inform. Agr. 19:37-46.

Patrick R, Palavage DM, 1994. The value of species as indicators of water quality. P. Acad. Nat. Sci. Phila. 145:55-92

Pavoni B, 2003. Nitriti e nitrati nelle acque e negli alimenti. Fertilizzanti 11:17-18.

Pieri L, Matzneller P, Gaspari N, Marotti I, Dinelli G, Rossi P, 2009. Bulk Atmospheric Deposition in the Southern Po Valley (Northern Italy). Water Air Soil Poll. 210:155-169.

Pieri L, Ventura F, Vignudelli M, Rossi P, 2011. Nitrogen balance in a hilly semi-agricultural watershed in Northern Italy. Ital. J. Agron. 6:e12.

Ponti M, Abbiati M, 2004. Quality assessment of transitional waters using a benthic biotic index: the case study of the Piallassa Baiona (Northern Adriatic Sea). Aquat. Conserv. 14:S31-S41.

Puckett LJ, Cowdery TK, Lorenz DL, Stoner JD, 1999. Estimation of nitrate contamination of an agro-ecosystem outwash aquifer using nitrogen mass balance budget. J. Environ. Qual. 28:2015-2025.

Regione Campania, 2003. Direttiva tecnica per il piano di utilizzazione agronomica dei reflui zootecnici (DGR 2302/2003).

Regione Lombardia, Direzione agricoltura, 2003. Disciplinari di produzione. PSR 2003 Misura F.

Rossi Pisa P, Vicari A, Gardi C, Catizone P, 1996. Il bacino idrografico come unità di indagine territoriale. Riv. Agron. 30:401-407.

Solimini AG, Bazzanti M, Ruggiero A, Carchini G, 2007. Developing a multimetric index of ecological integrity based on macroinvertebrates of mountain ponds in central Italy. Hydrobiologia 597:109-127. 
ison of three methodological approaches. Nutr. Cycl. Agroecosys.

Strickland JDH, Parsons TR, 1972. A practical handbook of seawater analysis. Bull. Fish. Res. Board Can. 167:311.

Tong STY, Chen W, 2002. Modelling the relationship between land use and surface water quality. J. Environ. Manage. 66:377-393.

Ventura M, Scandellari F, Ventura F, Guzzon B, Rossi Pisa P, Tagliavini $\mathrm{M}, 2008$. Nitrogen balance and losses through drainage waters in an agricultural watershed of the Po Valley (Italy). Eur. J. Agron. 29:108-115.

Watson CA, Atkinson D, 1999. Using nitrogen budget to indicate nitrogen use efficiency and losses from whole farming system: a compar53:259-267.

Zalidis G, Stamatiadis S, Takavakoglou V, Eskridge K, Misopolinos N, 2002. Impacts of agricultural practices on soil and water quality in the Mediterranean region and proposed assessment methodology. Agr. Ecosyst. Environ. 88:137-146.

Zettler ML, Frankowski J, Bochert R, Rohner M, 2004. Morphological and ecological features of Theodoxus fluviatilis (Linnaeus, 1785) from Baltic brackish and german freshwater population. J. Conchol. 38:304-316. 